\title{
Service Quality And Its Impact On Customer Satisfaction: An Empirical Evidence From The Pakistani Banking Sector
}

\author{
Hummayoun Naeem, Foundation University Institute of Engineering and Management, Pakistan \\ Asma Akram, Fatima Jinnah Women University, Pakistan \\ M. Iqbal Saif, Foundation University Institute of Engineering and Management, Pakistan
}

\begin{abstract}
This comparative research was designed to investigate the impact of service quality on customer satisfaction in the Pakistani banking sector. Hypothesis developed for the study was "higher level of service quality leads to higher level of customer satisfaction". A sample of two hundred respondents, (one hundred from a foreign bank and one hundred from a public sector I nationalized bank located in the twin cities of Rawalpindi and Islamabad) was drawn on the basis of simple random sampling. Various constructs of SERVQUAL model developed by Zeithaml and Bitner (1996) and five point customer satisfaction tool developed by Taylor and Baker (1994) were adopted and used for data collection. Data were analyzed through SPSS version 14. Results of the regression analysis indicated that service quality was proved to be a strong predictor of customer satisfaction in case of the foreign bank with the $R^{2}$ value of 0.644 accepting research hypothesis and rejecting null hypothesis as compared value $R^{2}$ of 0.156 that does not support the research hypothesis in case of public sector bank. The study concluded that service quality, if managed effectively, can contribute significantly towards customer satisfaction.
\end{abstract}

Keywords: Service Quality, Customer Satisfaction, Pakistani Banking Sector

\section{INTRODUCTION}

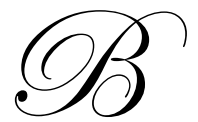

anks have their own significant role to play in the economic system of any country. Various types of banks perform various functions according to their prescribed roles defined by their memorandums and articles of association. Central bank is the bank of the government and is required to monitor and supervise the banking activities in a politically defined and specified geographical region. Agricultural and industrial banks cater for the needs of farmers and industrialists. Commercial banks generally have a wider network of their branches and look after the financial requirements of the general public (Mian, 2008). Commercial banks have maximum interaction with the general public and that is why, central banks are always keen to improve their service quality and productivity.

The most important factor that matters a lot in today's modern and successful banking business is the quality of services. Due to uniform policies of the central bank, all commercial banks are required to offer almost same services. But how these services are provided; that is the most important phenomenon. Ziethaml et al (1996) presented a model indicating various dimensions of service quality. The model was named SERVQUAL that elaborates service quality indicating its various constructs namely Tangibles, Reliability, Responsiveness, Empathy and Assurance.

Having discussed different aspects of the said service quality model, the next point comes to our mind is that why does this particular area get emphasized? The simple answer is "customer satisfaction". Most of the 
reputed business houses have their slogans based on the theme of the statement i.e. whatever we do is for our customers. This approach is very much in line with the following common phrases used by the marketing people: "customer is king"; "customer is always right". In light of the above discussion, it becomes obvious that customer is the center of all business activities. Following the same pedagogy, customer satisfaction thus becomes the ultimate objective of any business venture.

\section{PROBLEM STATEMENT}

Keeping in view the significance of service quality and customer satisfaction, a study is designed to examine the impact of service quality as an independent variable on dependent variable i.e. customer satisfaction.

\section{SIGNIFICANCE AND LIMITATIONS}

Every study has two parameters, one is theoretical contribution and the other one is applied aspects. Theoretical contribution is that either it is contributed by or it is a contribution to the body of knowledge. Applied aspects are that who is going to benefit from this research. The results and findings of the study would be applicable to the industry so that by taking this into account they can improve their productivity also. If the service quality effects negatively then it will decrease the productivity and as a result, profitability of the bank will decrease. The limitations are that scope of the study is restricted to the research plan i.e. the impact of service quality on customer satisfaction.

\section{OBJECTIVES OF THE STUDY}

The objectives of research are:

- $\quad$ To study the service quality level in nationalized and foreign banks in Pakistan.

- $\quad$ To examine the customer satisfaction level in nationalized and foreign banks in Pakistan.

- $\quad$ To test the relationship if any between the two variables i.e. service quality and customer satisfaction.

LITERATURE REVIEW

\begin{tabular}{|l|l|l|l|}
\hline $\begin{array}{c}\text { Serial } \\
\text { No. }\end{array}$ & Year & \multicolumn{1}{|c|}{ Author/Authors } & \multicolumn{1}{|c|}{ Contribution to the Body of Knowledge } \\
\hline 1 & 1996 & Ennew and Brinks & $\begin{array}{l}\text { The paper focuses on the relationship among service quality, customer } \\
\text { relationship and customer loyalty and concludes that compliance to } \\
\text { core ideas of service quality will generally result into customer } \\
\text { retention and profitability. }\end{array}$ \\
\hline 2 & 1997 & Yavas and others & $\begin{array}{l}\text { Studied that the success of service quality programs can be measured } \\
\text { by retention of existing customers. Furthermore, employees having } \\
\text { maximum interaction with the customers need to be satisfied so that } \\
\text { they could come up with quality services. }\end{array}$ \\
\hline 3 & 2003 & Jamal and Khattak & $\begin{array}{l}\text { The Study revealed that quality of services leads to customer } \\
\text { satisfaction and the tangible aspects of service environment have no } \\
\text { impact on customer satisfaction. }\end{array}$ \\
\hline 4 & 2003 & Sureshchandar and others & $\begin{array}{l}\text { The research indicates the shortage of adequate product knowledge in } \\
\text { improving the financial performance despite of detailed work on } \\
\text { service quality and market potentials. }\end{array}$ \\
\hline 5 & 2004 & Dean & $\begin{array}{l}\text { The research establishes a cause and effect relationship among } \\
\text { organizational features, employee attitudes to customer loyalty and } \\
\text { financial outcomes, concluding that organizational features and } \\
\text { employees' attitude influence service quality. }\end{array}$ \\
\hline 6 & 2005 & Gelade and Young & $\begin{array}{l}\text { The study examined relationship among organizational climate, } \\
\text { employee attitudes, customer satisfaction and sales performance. } \\
\text { Results indicate that the teamwork culture and job enablers support } \\
\text { organizational culture designed to serve customers efficiently. }\end{array}$ \\
\hline
\end{tabular}




\begin{tabular}{|c|c|c|c|}
\hline 7 & 2005 & Seth and Deshmukh & $\begin{array}{l}\text { The research analyzed service quality models and concluded that } \\
\text { customer expectation changes by elements such as time, interaction } \\
\text { with particular level of service quality and competitive environment. }\end{array}$ \\
\hline 8 & 2005 & Huseyin and others & $\begin{array}{l}\text { The study includes analysis and comparison of service quality in } \\
\text { commercial banks of Cyprus. Results reveal that customer expectations } \\
\text { are not fulfilled because of the gap found in empathy part of the } \\
\text { SERVQUAL model. }\end{array}$ \\
\hline 9 & 2005 & Carlo and others & $\begin{array}{l}\text { The study presents a framework focusing on quality of banking } \\
\text { services, resulting in the creation of five elements (customer } \\
\text { relationship, business transactions, information technology, branch and } \\
\text { its image) which can lead to quality in services targeting customer } \\
\text { satisfaction. }\end{array}$ \\
\hline 10 & 2006 & Al-Hawari and Ward & $\begin{array}{l}\text { The research was based on service quality and customers' role in } \\
\text { financial performance. Findings help in the formulation of marketing } \\
\text { strategies and proved customer satisfaction as a mediator in } \\
\text { relationship between retail banking and financial performance. }\end{array}$ \\
\hline 11 & 2006 & Festus and Maxwell & $\begin{array}{l}\text { The research investigated the typology of services and } \\
\text { operationalization scale clarifying the nature of service quality and its } \\
\text { relationship with customer satisfaction and behavioral intentions. }\end{array}$ \\
\hline 12 & 2007 & Yoo and Park & $\begin{array}{l}\text { The research was designed to analyze relationship among employees, } \\
\text { customers and financial performance. Results showed that employee } \\
\text { training and understanding has a significant impact on service quality. }\end{array}$ \\
\hline 13 & 2007 & Chang & $\begin{array}{l}\text { The research presents the formula of collective relationship banking as } \\
\text { a mechanism for monitoring customer information and identifies the } \\
\text { probability of banking relationship when borrowing firms have } \\
\text { different operating structures. }\end{array}$ \\
\hline 14 & 2007 & Mollenkopf and others & $\begin{array}{l}\text { The study focuses on the impact of return management system on } \\
\text { loyalty intentions. The resulting equation model identifies effects on } \\
\text { loyalty intentions occurring from customer satisfaction. }\end{array}$ \\
\hline 15 & 2007 & Astrid & $\begin{array}{l}\text { Research results indicate that markets remain concentrated, number of } \\
\text { dominant banks remains almost constant across markets and most } \\
\text { importantly, service quality increases in larger markets and is higher in } \\
\text { larger banks because of their good will in the market. }\end{array}$ \\
\hline
\end{tabular}

It may concluded from the above discussions that customer satisfaction is always taken as a central point in almost all business ventures. There are various factors that actually generate customer satisfaction. Service quality is one of them. There has not been any scientific study where service quality has been taken as an independent variable to study customer satisfaction as a dependent variable specifically in commercial banking sector. Keeping in view this gap in the body of knowledge, this study has been designed to examine the impact of service quality on customer satisfaction in the selected banks from the Pakistani banking sector.

\section{METHODOLOGY}

The universe for the present study consisted of two leading banks operating in Pakistan. One dealing with the foreign sector i.e. Citibank, a leading American Bank having branches all over the country and the other one from the public sector i.e. National Bank of Pakistan, having a wider network of branches all over the country.

\section{RESEARCH QUESTION}

What is the impact of service quality on customer satisfaction of banks?

\section{HYPOTHESIS}

The greater the service quality of the bank, the higher will be the customer satisfaction. 
There are two variables involved; Independent Variable is Service Quality and its various constructs are Reliability, Assurance, Tangibles, Empathy, and Responsiveness. The dependent variable is Customer Satisfaction.

\section{SAMPLING DETAILS}

A sample of two hundred respondents, (one hundred from a foreign bank and one hundred from a public sector / nationalized bank located in the twin cities of Rawalpindi and Islamabad) was drawn on the basis of simple random sampling from the list of active customers. Sample details are as follows:

Table No. 1

Final Sample for the Study

\begin{tabular}{|l|c|}
\hline \multicolumn{1}{|c|}{ Bank } & Active Customers \\
\hline Citi Bank & 100 \\
\hline National Bank & 100 \\
\hline Total & 200 \\
\hline
\end{tabular}

Source: Bank data and researcher's own processing

\section{SCALE AND DATA ANALYSIS}

A five point Likert Scale starting from strongly disagree to strongly agree $(1-5)$ was used for the study. Data analysis was carried out through SPSS software package (SPSS Inc, 2000) version 14.

Abbreviations: CB for Citibank and NBP for National Bank of Pakistan

\section{DEMOGRAPHIC CHARACTERISTICS OF THE SAMPLE}

- A dominant majority (74.0\%) of the customers from CB were below the age of 40 . In case of NBP, majority (67.0\%) of the respondents were in the age group of 20 to 40 . The data indicated that CB had a dominating majority of young customers. This seems to be the CB strategy to hire young people with modern and broader vision.

- A heavy majority ( $95 \%$ ) of the CB customers were bachelors and master degree holders whereas $91 \%$ were of the same qualifications in case of NBP. Education level of the officers of both the banks appeared to be generally the same.

- $\quad$ Citi Bank was found to have $96.0 \%$ of male customers and $4.0 \%$ female customers. In case of NBP, overwhelming majorities $(98.0 \%$ ) of the customers were male and almost $2.0 \%$ were female.

\section{TESTING OF HYPOTHESIS THROUGH REGRESSION ANALYSIS}

For empirical analysis, the researcher used service quality as an independent variable and customer satisfaction as a dependent variable. Testing of hypothesis is performed through regression analysis:

$\left(\mathbf{H}_{1}\right)$ The greater the service quality of the bank, the higher will be the customer satisfaction.

$\left(\mathbf{H}_{\mathbf{0}}\right) \quad$ There is no relationship between service quality and customer satisfaction.

Table No. 2

Regression Analysis

Service Quality and its Impact on Customer Satisfaction

\begin{tabular}{|c|c|c|c|c|c|c|c|c|c|}
\hline \multicolumn{2}{|l|}{$\mathbf{C B}$} & \multicolumn{3}{|l|}{$\mathrm{N}=100$} & \multicolumn{5}{|c|}{ NBP $\quad \mathrm{N}=100$} \\
\hline $\mathrm{R}$ & $\mathrm{R}^{2}$ & Adjusted $\mathrm{R}^{2}$ & F Statistics & P Value & $\mathrm{R}$ & $\mathrm{R}^{2}$ & Adjusted $\mathrm{R}^{2}$ & F Statistics & P Value \\
\hline 0.815 & 0.664 & 0.661 & 193.877 & 0.000 & 0.395 & 0.156 & 0.147 & 18.115 & 0.000 \\
\hline
\end{tabular}

Source: Field Data 
The above table indicates a strong relationship $(0.815)$ between the two variables in case of Citibank. $\mathrm{R}^{2}$ value is 0.664 indicating that service quality is a strong predictor of customer satisfaction. The situation is opposite in case of National Bank. Data reveal a weak relationship between the independent and dependent variable. The results of the empirical analysis indicate that if service quality is monitored carefully, this can improve customer satisfaction.

\section{APPLICATION OF T TEST}

Two independent samples were also analyzed with the application of $t$ test. In both cases i.e. service quality and customer satisfaction, strong $t$ values were recoded ranging from 13 to 17 indicating a significant difference between the two sets of samples.

\section{CONCLUSION}

Based on the findings and data analysis, following conclusions have been drawn:

1. Customers of foreign bank perceived high level of service quality whereas customers of nationalized bank experiences low level of service quality form the bank personnel. The difference has also been statistically verified through the application of $t$ test.

2. It is further concluded that service quality is a strong predictor of customer satisfaction in case of foreign bank whereas the situation is vice versa in case of nationalized bank.

The empirical evidence shows that public sector banks are unable to manage the factors influencing quality as well customer satisfaction. On the other hand, foreign sector banks are keen to improve upon such issues. The data proves that there is a significant relationship between service quality and customer satisfaction.

\section{RECOMMENDATIONS}

Based on the findings and conclusion of the study, following actions are recommended for implementation by the banks involved:

- $\quad$ HR investments are to be made very carefully. Fresh blood induction is to be encouraged. As the employees of NBP are mostly older and senior people. So, the bank should hire young and highly educated people. That would result in the increase of their efficiency level.

- $\quad$ NBP employees should show their more commitment to provide efficient services to its customers.

- $\quad$ NBP needs to make arrangements for longer business hours.

\section{FUTURE RESEARCH}

- $\quad$ The sample size of 200 respondents is small to measure service quality and customer satisfaction. Another study may be designed with a larger sample size.

- $\quad$ During literature survey, it was found that different other methods and models have been used to evaluate the service quality of banks. A study may be designed while using such models.

\section{AUTHOR INFORMATION}

Hummayoun Naeem is an Assistant Professor in the Faculty of Management Sciences, Foundation University, Islamabad. His area of specialization is banking and research issues in management. Before joining the University, he served commercial banking sector for almost one decade mainly in managerial capacity with specialization in branch banking operations. While combining his industrial and teaching experience, he developed a TQM Model for Commercial Branch Banking Operations during his $\mathrm{PhD}$ from the same university. He has several local and international conference and journal publications to his credit. 
Asma Akram has completed her Masters in Business Administration from Fatima Jinnah Women University, Rawalpindi with specialization in management. She is currently working for a chartered accountancy firm in Islamabad. She intends to get herself registered in the doctoral program in future.

M. Iqbal Saif is heading the Faculty of Management Sciences, Foundation University, Islamabad. Before joining this University, he served University of the Punjab, Lahore, Allama Iqbal Open University, Islamabad and Gomal University, D. I. Khan as a Department Head. He is the pioneer of PhD program in the Faculty of Management Sciences. His area of specialization is sociological analysis of contemporary business issues, dynamics of organizational behavior, quality management, research methodology and human resource development. He is author of various books on research methodology and human resource development. He has a number of local and international conference and journal publications to his credit.

\section{REFERENCES}

1. Al-Hawari M. and Ward, T. (2006). The Effect Of Automated Service Quality On Australian Banks' Financial Performance And The Mediating Role Of Customer Satisfaction. Marketing Intelligence \& Planning, Volume: 24 Issue: 2 ISSN: 0263-4503. pp.153-174

2. Astrid, A. D. (2007). Market Size, Service Quality, and Competition in Banking. Journal of Money, Credit and Banking. Volume 39, Issue 1, pp. 49-81.

3. Carlo, G. I. and others (2005). Service Quality in Banks: Insights from the Brazilian Experience. Journal of Internet Banking and Commerce, Vol. 10, No.3. (http://www.arraydev.com/commerce/jibc/). Retreived on Thursday 30 July, 2009

4. Chang, Y. T. (2007). Collective Relationship Banking and Private Information Monitoring In Korea. The Economics of Transition 15 (3), Volume 15 Issue 3 Page 483-504.

5. Dean, A. M. (2004). Links Between Organizational And Customer Variables In Service Delivery. International Journal of Service Industry Management, Vol. 15, No. 4, pp. 332-350

6. Ennew, T. C. and Brinks M. R. (1996). The Impact of Service Quality and Service Characteristics on Customer Retention: Small Businesses and their Banks in the UK. British Journal of Management, Volume 7 Issue 3, pp. 215-250

7. Festus, O. and Maxwell K. H. (2006). A Typology Analysis of Service Quality, Customer Satisfaction and Behavioral Intentions in Mass Services”, Managing Service Quality, Volume: 16 Issue: 2 Page: 106 - 123.

8. Gelade, G. A. and Young, S. (2005). Test Of A Service Profit Chain Model In The Retail Banking Sector", Journal Of Occupational And Organizational Psychology, Vol. 78, pp. 1-22

9. Huseyin, A. and others (2005). A Comparison Of Service Quality In The Banking Industry: Some Evidence From Turkish- And Greek-Speaking Areas In Cyprus, International Journal Of Bank Marketing, Volume: 23, Issue: 7, pp. $508-526$

10. Jamal, A. and Khattak, N. (2003). Factors influencing Customer Satisfaction In Retail Banking Sector In Pakistan. International Journal of Commerce and Management, Volume: 13 Issue: 2 , pp. $29-53$

11. Mian, R. A. (2008). Money Banking and Finance. Azeem Academy Publishers, Lahore.

12. Mollenkopf and others. (2007). Managing Internet Product Returns: A Focus on Effective Service Operations Decision Sciences 38(2),215-250.Volume 38, Issue 2, pp. 215-250

13. Seth N. and Deshmukh, S. J. (2005). Service Quality Models: A Review. International Journal of Quality \& Reliability Management, vol. 22, no 9, pp. 913-949

14. Sureshchandar, G. S. and others. (2002). Management Perceptions of Quality Service in the Banking Sector of a Developing Economy - A Critical Analysis. International Journal of Bank Marketing. Vol. 20, Issue 4, pp.181-196

15. Taylor, S.A. and Baker, T.L. (1994). An assessment of the relationship between service quality and customer satisfaction in the formation of consumers' purchase intentions, Journal of Retailing, Vol. 70 No.2, pp.163-78.

16. Yavas, U. and others. (1997). Service Quality In The Banking Sector In An Emerging Economy: A Consumer Survey. International Journal of Bank Marketing, Volume: 15, Issue: 6 pp. 217 - 223.

17. Yoo, K. Y. and Park, J. A. ( 2007) Perceived Service Quality: Analyzing Relationships Among Employees, Customers, And Financial Performance, International Journal of Quality \& Reliability Management, Volume: 24 Issue: 9. I, pp. 316-326

18. Ziethaml, A. V. and Bitner, M. J. (1996). Services Marketing. McGraw Hill Inc., Singapore. 